\title{
Pharmaceutical Study of Kanta Lauha and Teekshna Lauha Bhasma
}

\section{Research article}

\author{
Subhash Chandra Bhargava ${ }^{1}$, K. R. C. Reddy $^{2 *}$ \\ 1. JR-III, 2. Associate Professor, \\ Dept. of Rasa Shastra, Faculty of Ayurveda, IMS, BHU, Varanasi.
}

\begin{abstract}
The Ayurvedic medicines are formulated by using plant, animal, metal and minerals. Conversion of metals and minerals into acceptable form i.e. bhasma is a unique technology of Ayurveda. Certain technical procedures like Sodhana, Marana (Incineration process) etc. will play a greater role in converting the material into acceptable form. GMP provides certain directions for processing these medicines in present day. Standard operative procedure, particularly for bhasma preparation has become mandatory for the standardization and quality control of bhasmas. By considering these views in present research work the different samples of lauha bhasma were prepared by using different raw materials viz. Magnetite iron ore, iron turnings. As per the description of Ayurveda, Kanta lauha (Magnetite iron ore) is considered as best raw material for lauha bhasma preparation. After this next best raw material for lauha bhasma preparation is Teekshna lauha (iron turnings). The availability of Kanta lauha (magnetite iron ore) is rare, hence in many Ayurvedic pharmaceutical industries, lauha bhasma is prepared by Teekshna lauha. In the present work a step is made to find out the best quality of lauha bhasma by preparing various samples of lauha bhasma.
\end{abstract}

Key words: Teekshna lauha, Kanta lauha, bhasma, Sodhana, Marana

\section{Introduction}

Ayurveda is the science of life dealing with healthcare of living being since ancient period. The Ayurvedic drugs are obtained from natural sources only i.e. from plants, animals and minerals. Conversion of metals and minerals into acceptable form i.e. bhasma is a unique technology of Ayurveda. Various procedures like Sodhana, Marana (Incineration process) etc. applied for the

\footnotetext{
*Corresponding author:

Dr. KRC Reddy

Associate Professor,

Dept. of Rasa Shastra, Faculty of Ayurveda, Institute of Medical Sciences, Banaras Hindu University, Varanasi.

Email :drkrcreddybhu@yahoo.co.in
}

preparation of bhasma, will play a greater role in converting the material into acceptable form. By considering these views in present research work the different samples of lauha bhasma were prepared by using different raw materials viz. Magnetite iron ore, iron turnings. In Ayurvedic literature, Kanta lauha (Magnetite iron ore) is considered as best raw material for lauha bhasma preparation. After this next best raw material for lauha bhasma preparation is Teekshna lauha (iron turnings). The availability of Kanta lauha (magnetite iron ore) is rare, hence in many Ayurvedic pharmaceutical industries, lauha bhasma is prepared by Teekshna lauha. In the present work a step is made to find out the best quality of lauha bhasma by preparing various samples of lauha bhasma. Two 
samples of Kanta lauha and one sample of Teekshna lauha was used for the preparation of lauha bhasma.

\section{Materials and Methods}

In present thesis work, the pharmaceutical study was conducted in three batches which are mentioned below.

Batch "A" : Teekshna lauha
(Iron turning)

Batch "B" : $\quad$ Kanta lauha
(Magnetite iron ore)

Batch "C" : Kanta lauha
(Magnetite iron ore)

\section{Procurement of Raw Material}

$>\quad$ Teekshna lauha (Iron Turnings) were collected from Dept. Of Metallurgy, IT, BHU, VARANASI.

$>\quad$ Kanta lauha (Magnetite iron ore) were collected from NML Jamshedpur (JHARKHAND).

$>$ Tila taila was collected from Ayurvedic Pharmacy, BHU, VARANASI.

$>\quad$ Gomutra was collected from Dairy farm, Institute of Agriculture sciences, BHU, VARANASI.

$>\quad$ Triphala and Kulattha collected from Gola Dinanath, VARANASI.

\section{Pharmaceutical Processing}

(I) Sodhana

\section{(A) Samanya Sodhana}

(a) Preparation of Takra, (b) Preparation of Kanji, (c) Preparation of Kulattha Kwatha, (d) Process of Samanya Sodhana

\section{(B) Visesha Sodhana}

(a)Preparation of Triphala Kwatha,

(b)Process of Visesha Sodhana

\section{(II) Marana}

\section{(A) Bhanupaka}

(a) Preparation of Triphala Kwatha, (b) Process of Bhanupaka
(B)
Sthalipaka

(a) Preparation of Triphala Kwatha, (b) Process of Sthalipaka

\section{(C)Putapaka}

(a) Preparation of Triphala Kwatha, (b) Process of puta paka

Method: Curd along with water (half the amount of curd) was taken and it was mixed homogeneously with the help of mixer grinder. After proper mixing whole butter portion of takra were removed. Then it was used for samanya sodhana of lauha.

\section{Chief desired character}

Viscosity of curd was changed. Curd was homogenously mixed with water. Test of takra was amla rasa.

(b) Preparation of anji $^{[2]}$

$>\quad$ Principle- Fermentation

$>\quad$ Ingredients- Rice, Water, Masha, Redish.

$>\quad$ Equipments- Heating device, Stainless steel container, Plastic container, Spatula.

Method: First the rice and masha (in appropriate quantity) were cooked properly by adding sufficient quantity of water. After cooking the material, small pieces of radish were added into it. Then whole material was transferred into a plastic container. Then the mouth of container was tightly closed and kept for fermentation for 15-20 days. After the completion, test (Sound, Match stick and Amla rasa.) was performed and prepared kanji was collected for sodhana process.

\section{Completion test}

Hissing sound was not produced. Match stick was burning continuously when it was kept over the mouth of container. 
Taste of kanji was amla rasa. Whitish colour of kanji was appeared.

\section{(c) Preparation of kullatha kwatha \\ Ingredients- Kullatha- 6 \\ kg., Water- 48 lit. \\ Equipments- Heating device, Stainless steel container, Spatula, Cotton cloth etc.}

Method: Above mentioned quantity of kullatha and water was taken in an iron container and it was subjected to boiling on mild temperature till $1 / 4^{\text {th }}$ part of the water reduces. Then it was used for samanya sodhana of lauha.

\section{Batch "A" - Teekshna lauha (Iron turnings)}

Process of Samanya Sodhana
$>\quad \begin{aligned} & \text { Apparatus- Koshti, } \\ & \text { container, Spatula, Iron } \\ & \text { mesh etc. }\end{aligned}$
$>\quad \begin{aligned} & \text { Ingredients- Lauha } \\ & \text { turnings)-500 gm. }\end{aligned}$
$>\quad$ Tila taila- QS.
$>\quad$ Takra- QS.
$>\quad$ Gomutra- QS.
$>\quad$ Kanji- QS.
$>\quad$ Kullatha Kwatha- QS.

\section{Samanya Sodhana by tila taila}

Method: Iron turnings were collected in an iron container which was kept over the koshti (furnace) and heated the material till it becomes red hot. Thereafter this material was quenched in tila taila, which was collected in another container. Same procedure was repeated six more times (Total seven times). Each time fresh tila taila was taken (Approx. 500ml). After completion, material was filtered by iron mesh and dried it.

- $\quad$ Average temp. of heating device : $1100^{\circ} \mathrm{C}$

- Average temp. of surface of container : $1000^{\circ} \mathrm{C}$
- Average temp. of red hot iron turning : $900^{\circ} \mathrm{C}$

Observations: First time iron turning took 28 minute to become red hot. The duration was lowered at later stages. When red hot iron turning was quenched in tila taila, it was kept the fire promptly. Colour of iron turning was turned from shiny to black. It was sticky in nature due to adhesion of tila taila on the surface of iron turnings. On next heating iron turning was also catch the fire

\section{Samanya Sodhana by Takra}

Method: After sodhana by tila taila iron turnings were collected in an iron container which is kept over the Koshti (furnace) and heated the material till red hot. Thereafter this material was quenched in takra, which was collected in another container. Same procedure was repeated six more time (Total seven times). Each time fresh takra was taken. Then material was filtered by iron mesh and dried it.

Observation: Iron turning took 15-20 minute to get red hot state for first time then time duration was further lowered. After quenching takra was started boiling. Iron turning get started to convert into smaller pieces. Some fine particles of iron were come out from vessel during quenching. Colour of iron turned to grayish black. Colour and consistency of takra was also changed after quenching.

\section{Samanya Sodhana by Gomutra-}

Method : After sodhana by takra, iron turnings were collected in an iron container which is kept over the koshti (furnace) and heated the material till red hot. Thereafter this material was quenched in Gomutra, which was collected in another container. Same procedure was repeated six more time (Total seven times) each time fresh Gomutra was taken. Then material was filtered by iron mesh and dried it.

Observations: After quenching peculiar smell was observed. Colour of cow urine changed from yellow to blackish red. 
Colour of iron turning also changed from black to reddish brown. Iron turning was decreasing in size further.

\section{Samanya Sodhana by Kanji}

Method: Iron turnings were collected in an iron container which is kept over the koshti (furnace) and heated the material till red hot. Thereafter this material was quenched in Kanji, which was collected in another container. Same procedure was repeated six more time (Total seven times). Each time fresh Kanji was taken. Then material was filtered by iron mesh and dried it.

Observations: Iron turnings took 10-12 min. to obtain red hot state. Further it was lowered. Kanji was started boiling after quenching the red hot iron turnings. Iron turnings were converted to smaller pieces. Colour of iron turning was also changed from reddish brown to black.

\section{Samanya Sodhana by Kullatha Kwath}

Iron turnings were collected in an iron container which was kept over the koshti (furnace) and heated the material till red hot. Thereafter this material was quenched in Kullatha kwatha, which was collected in another container. Same procedure was repeated six more time (Total seven times) each time fresh Kullatha kwatha was taken. Then material was filtered by iron mesh and dried it.

Observations: Iron turnings took 08-10 min. to obtain red hot state. Further it was lowered. Kullatha kwatha started boiling after quenching. Colour of kullatha kwatha was changed after quenching from red to blackish red. Particle of iron turning become smaller.

\section{(B) Visesha Sodhana of lauha}

(a) Preparation of Triphala kwatha for Visesha sodhana ${ }^{[3]}$

Principle- Heating.

Equipments- Heating devices, Stainless steel container, Spatula, Iron mesh etc.

Ingredients- Lauha (Iron turnings)- 520gm

Triphala

kwatha - QS. (Approx.

$600 \mathrm{ml})$

\section{(b) Process of Visesha sodhana}

Method: Samanya sodhita Teekshna Lauha (iron turnings) was collected in an iron container which was kept over the koshti (furnace) and heated the material till into red hot state. Thereafter this material was quenched in Triphala kwatha, which was collected in another container. Same procedure was repeated six more time (total seven times). Each time fresh Triphala kwatha was taken. Then material was filtered by iron mesh and dried it.

Table No. 1. Showing observations before and after Visesha sodhana of Teekshna lauha (Iron turning).

\begin{tabular}{|l|c|c|}
\hline Iron turning & $\begin{array}{c}\text { Before } \\
\text { Visesha } \\
\text { Sodhana }\end{array}$ & $\begin{array}{c}\text { After } \\
\text { Visesha } \\
\text { Sodhana }\end{array}$ \\
\hline Colour & Black & Dark black \\
\hline Consistency & brittle & More brittle \\
\hline Appearance & $\begin{array}{c}\text { Small } \\
\text { peaces }\end{array}$ & $\begin{array}{c}\text { More small } \\
\text { peaces }\end{array}$ \\
\hline Weight & $520 \mathrm{gm}$ & $610 \mathrm{gm}$ \\
\hline
\end{tabular}

Reason of wt. gain: Due to adding of contents of Triphala kwatha. Out of this $10 \mathrm{gm}$ was taken as sample for analysis.

\section{(II) Marana of lauha}

For the marana of lauha Rasendra Sara Samgraha was followed, in this text process of marana is completed in three steps, they are as follow-
(I) Bhanupaka
(II) Sthalipaka,
(III) Putpaka

\section{(I) Bhanupaka}

Equipments required- iron tray, spatula' 
Ingredients- Lauha churna- 600 gm. Triphala kwatha- QS.

\section{Preparation of Triphala Kwatha for Bhanupaka $^{[4]}$}

Method : Triphala along with double the amount of water was boiled till it reduced to $1 / 4^{\text {th }}$ the volume of water.

Method of Bhanupaka: Lauha churna collected from Visesha sodhana was kept in an iron tray and Triphala Kwatha added till completely dipped the lauha churna (Approx. 300ml.). Thereafter material was mixed together uniformly and tray was kept in sunlight till the moisture contents evaporate completely. Same process was repeated for six more times (total seven times).

Observations: It was taking 2-3 days for completely drying. Colour of lauha churna was turned to dark black. Big particles of lauha churna were converted into fine particles. Brittleness of lauha churna was increased.

\section{(II)Sthalipaka ${ }^{[5]}$}

Equipments required- Heating device, iron container, spatula.

Ingredients- Lauha churna- 1300 gm. Triphala kwatha- QS.

\section{Preparation of Triphala kwatha for sthalipaka}

Procedure - Triphala kwatha is prepared by taking triphala three times of lauha, $16^{\text {th }}$ times of water was added to it. The whole material is boiled in stainless steel container to reduce to $1 / 8^{\text {th }}$ of original volume of water.

Method of sthalipaka: First of all the amount of lauha churna was taken in an iron container (frying pan or cauldron) and triphala kwatha was added in sufficient quantity. Then it was subjected to kept over the heating device and get intense heat till completely evaporated the water contents of triphala kwatha. This process was repeated for six more times (Total seven times). (R.T.20/25-30, R.S.S.1/308)
Observations: During heating it was adhering to the surface of the container. Fumes were appearing due to burning of triphala. Smell of burning triphala was observed. Colour of lauha churna was turned to grayish black.

\section{(II) Putpaka 6}

Equipments required- Earthen pot, Electric muffle furnace, Mortar and pestle etc.

Ingredients- Lauha churna- 2280 gm. Triphala Kwatha- QS.

According to Rasendra sara sangraha lauha bhasma should be prepared by triturating with swarasa of triphala and subjected to puta. But in case of unavailability of the swarasa, bhasma should be prepared by triphala kwatha.

Method: Above mentioned quantity of lauha churna was triturated in Mechanized kharal with Triphala Kwatha and then it was subjected to made chakrika (pallets) then dried till the completely get loss the moister contains. There after these pallets were collected into small earthen pot (sarava) and placed uniformly, after this earthen pot was covered by same size another earthen pot and prepared a structure like samputa. After this, the samputa was kept in electric muffle furnace and temperature gradually increased up to $600^{\circ} \mathrm{c}$, Frequency 30 and maintained for one hour. Then the furnace was switched off and left for self cooing. The next day after the swangasitala the samputa was collected and opened and internal pellets were collected. Same process of puta was repeated till proper Bhasma was not prepared (total 20 times).

The observation of pallets and materials at different no. of putas is mentioned below.

$1^{\text {st }}$ puta:It was taking 8 hour to get converted in pest like structure to made pellets. Due to coarse powder of materials, it was very difficult to made pellets. Temperature was set at $600^{\circ} \mathrm{C}$ and frequency at 30. It was attain in 1 hour and 10 min. During puta fumes with specific 
odour were observed, when temperature was reached at $150^{\circ} \mathrm{C}$. After puta colour of pellets was black. Surface of pellets was rough. After puta whole material was remain half of the original volumes, because of triphala contents which were added during bhanupaka and sthalipaka, burnt during putapaka.

$2^{\text {nd }}$ puta: Material was triturated Approx. 6 hour. Pellets were made easily due to it was finer than previously. Surface of pellets were rough. Temperature was same as previous. After puta colour of pellets was blueish black. But surface of some pellets were brown in colour. After trituration it was again black in colour.

$3^{\text {rd }}$ puta: Material was triturated Approx. 6 hour. Particle size of lauha bhasma was also decrease. Colour of pellets was reddish brown on the superior surface but inferior surface are black in colour. After trituration it was turned to grayish black. Temperature setting was same as previous. After puta pellets were soft and easily breakable by hand.

$4^{\text {th }}$ puta: Same as previous.

$5^{\text {th }}$ puta: Pellets were soft in consistency and easily breakable. Colour of pellets was reddish brown. Surface of pellets was smooth.

$\boldsymbol{6}^{\text {th }}$ puta: Pellets were soft in consistency and easily breakable. Colour of pellets was reddish brown.Surface of pellets was smooth.

$7^{\text {th }}$ puta: Same as previous puta.

$8^{\text {th }}$ Puta: Pellets were soft they were getting broken by mild pressure of finger. Colour of pellets was same as previous.

$9^{\text {th }}$ Puta: Same as previous puta.

10 ${ }^{\text {th }}$ Puta: Hardness of pellets was increased. Colour of pellets was turned to reddish black. Black spots were found over some pellets.

$1^{\text {th }}$ Puta

Observation: Same as previous.

12 $^{\text {th }}$ Puta: Pellets were hard on breaking by hand. Bhasma was become Rekhapurna about $40 \%$. Material was become sticky after triturating in khalva.

13 $^{\text {th }}$ Puta: Same as previous.

$14^{\text {th }}$ Puta: Same as previous.

15 $^{\text {th }}$ Puta: Pellets were little hard. Blackish spots were found on the surface of pellets. Bhasma was became $50 \%$ rekhapurna. 40\%bhasma was found positive in varitara test. Loss of material$20 \mathrm{gm}$.

$16^{\text {th }}$ Puta: Colour of bhasma was turned to blackish red i.e. pakvajambuphala varna. Bhasma was $60 \%$ rekhapurna. It was $50 \%$ found positive in varitara test. On the trituration material became sticky in nature.

17 ${ }^{\text {th }}$ Puta: On trituration in kharal gritty appearance of bhasma was observed. Colour of bhasma was same as previous puta. Bhasma was $65 \%$ rekhapurna. $50 \%$ bhasma was found positive in varitara test.

$18^{\text {th }}$ Puta: Pellets were now soft and could be broken easily by hand. Colour of bhasma was blackish red. Bhasma was $70 \%$ rekhapurna. $60 \%$ bhasma was found positive in varitara test.

19 ${ }^{\text {th }}$ Puta: Pellets were soft and could be broken easily by hand. Colour of bhasma was blackish red. Bhasma was $75 \%$ rekhapurna. $65 \%$ bhasma was found positive in varitara test.

20 ${ }^{\text {th }}$ Puta: Pellets were soft and could be broken easily by hand. Colour of bhasma was blackish red i.e. pakvajambuphala Varna. Bhasma was $95 \%$ rekhapurna. $75 \%$ bhasma was found positive in varitara test.

BATCH "B": Batch "B" was prepared at the same method and same temperature which was adapted for batch "A". Details of findings and observations are given below.

Batch "B"- Kanta lauha (Magnetite iron ore)

Samanya Sodhana by tila taila

Method-Same as batch A 
Observations: First time Kanta lauha took 20 minute to obtain red hot state. The duration was lowered at later stages. When red hot Kanta lauha was quenched in tila taila, it was also kept the fire same as Teekshna lauha. Colour of Kanta lauha was turned from brownish black to dark black. It was sticky in nature due to adhesion to tila taila on the surface of Kanta lauha. After first time Kanta lauha was also catch the fire on next heating.

\section{Samanya Sodhana by Takra}

Method-Same as Batch A

Observations: First time Kanta lauha took 20 minute to obtain red hot state. The duration was lowered at later stages. When red hot Kanta lauha was quenched in takra, it was stared boiling. Colour of Kanta lauha was dark black. Colour of takra was also changed. After quenching big particle of Kanta lauha was break into smaller size.

\section{Samanya Sodhana by Gomutra}

Method-Same as Batch A

Observation: Lauha took $15 \mathrm{~min}$. to get red hot state for first time then time duration was further lowered. After quenching peculiar smell was observed. Colour of cow urine was changed from yellow to reddish black. Colour of Kanta lauha was also changed from black to reddish black. Kanta lauha was decreasing in size further.

\section{Samanya Sodhana by Kanji-}

Method - Same as Batch A

Observations: Kanta lauha took 10-12 min. to obtain red hot state. Further it was lowered. Kanji was started boiling after quenching the red hot Kanta lauha. Kanta lauha were converted to smaller pieces. Colour of Kanta lauha was black. Colour of Kanji was also changed.

\section{Samanya Sodhana by Kullatha Kwatha}

Method- Same as Batch A

Observations: Kanta lauha took 08-10 min. to obtain red hot state. Further it was lowered. Kullatha kwatha was started boiling after quenching. Colour of kullatha $k w a t h a$ was changed after quenching from red to blackish red. Particle of Kanta lauha become smaller.

(B) Visesha Sodhana of lauha

Method- Same as Batch A

Table No. 2. Showing observations before and after Visesha sodhana of Kanta lauha (Magnetite iron ore).

\begin{tabular}{|l|c|c|}
\hline Kanta lauha & $\begin{array}{c}\text { Before } \\
\text { Visesha } \\
\text { Sodhana }\end{array}$ & $\begin{array}{c}\text { After } \\
\text { Visesha } \\
\text { Sodhana }\end{array}$ \\
\hline Colour & $\begin{array}{c}\text { Brownish } \\
\text { black }\end{array}$ & Dark black \\
\hline Consistency & brittle & $\begin{array}{c}\text { More } \\
\text { brittle }\end{array}$ \\
\hline Appearance & $\begin{array}{c}\text { Small } \\
\text { peaces }\end{array}$ & $\begin{array}{c}\text { More small } \\
\text { peaces }\end{array}$ \\
\hline Weight & $500 \mathrm{gm}$ & $530 \mathrm{gm}$ \\
\hline
\end{tabular}

(II) Marana of Kanta lauha: Same as Batch A

(I) Bhanupaka-

Equipments required- iron tray, spatula'

Ingredients- Kanta Lauha churna- 510 gm. Triphala kwatha- QS.

Preparation of Triphala Kwatha for Bhanupaka: Same as Batch A

Method of Bhanupaka: Same as Batch A

Observations: It was taking 2-3 days for completely drying for first avartana. First time quantity of triphala kwatha was $300 \mathrm{ml}$ to be used and further it was slightly increased. Colour of Kanta lauha churna was dark black. Big particles of Kanta lauha churna were converted into small particles. After completion quantity of Kanta lauha was increased about two to three times of original weight.

(II) Sthalipaka

Equipments required- Heating device, iron container, spatula. 
Ingredients- Lauha churna- 1240 gm. Triphala kwatha- QS.

\section{Method of sthalipaka: Same as Batch A}

Observations: During heating it was adhering to the surface of the container. Fumes and odour was appearing due to burning of triphala. Colour of Kanta lauha churna was turned to grayish black.

\section{(III) Putpaka}

Equipments required- Earthen pot, Electric muffle furnace, Mortar and pestle etc. Ingredients- Lauha churna- 1960 gm. Triphala Kwath- QS.

\section{Method: Same as Batch A}

$1^{\text {st }}$ puta: It was taking 8 hours to get convert into pest like structure to make pellets. Due to coarse powder of materials, it was very difficult to make pellets. Temperature was set at $600^{\circ} \mathrm{C}$ and frequency at 30 . It was attain in 1 hour and 10 min. During puta fumes with specific odour were observed, when temperature was reached at $200^{\circ} \mathrm{C}$. After puta colour of pellets was black. Surface of pellets was rough. After puta whole material was remain half of the original volumes, because of triphala contents which were added during bhanupaka and sthalipaka, burnt during putapaka. After triturating again powder was converted into black colour.

$2^{\text {nd }}$ puta: Material was triturated approx. 6 hours. Pellets were made easily due to it was finer than previously. Surface of pellets were rough. After puta colour of pellets was bluish black. But surface of some pellets were brown in colour. Pellets were soft and easily breakable by hand. After trituration it was again black in colour.

$3^{\text {rd }}$ puta: Material was triturated approx. 6 hours. Particle size of lauha bhasma was also decrease. Colour of pellets was reddish brown on the superior surface but inferior surface was black in colour. After puta, pellets were looking like tattered. After trituration it was turned to black.
After puta pellets were soft and easily breakable by hand.

$4^{\text {th }}$ puta: Pellets were soft in consistency which is easily breakable by hand. Colour of pellets was reddish brown but inside it was black. After trituration it was brown in colour.

$5^{\text {th }}$ puta: Pellets were soft in consistency and easily breakable. Colour of pellets was reddish brown. Surface of pellets was slightly rough. $25 \%$ bhasma was rekhapurna.

$6^{\text {th }}$ puta: Same as previous puta.

$7^{\text {th }}$ puta: Same as previous puta.

$8^{\text {th }}$ Puta: Pellets were soft they were getting broken by mild pressure of finger. Colour of pellets was same as previous.

$9^{\text {th }}$ Puta: Same as previous puta.

10 ${ }^{\text {th }}$ Puta: Pellets were little hard then previous. Colour of pellets was turned to reddish black. Surface of pellets was smooth. $40 \%$ bhasma was found positive in rekhapurna test.

$1^{\text {th }}$ Puta: Same as previous.

$12^{\text {th }}$ Puta: Pellets were soft on breaking by hand. Bhasma was become Rekhapurna about $50 \%$. Material was rough during triturating in khalva.

$13^{\text {th }}$ Puta: Same as previous.

$14^{\text {th }}$ Puta: Same as previous.

15 $^{\text {th }}$ Puta: Pellets with little hard and Blackish spots were found on the surface of pellets. Bhasma was became $60 \%$ rekhapurna. $50 \%$ bhasma was found positive in varitara test.

16 $^{\text {th }}$ Puta: Colour of bhasma was turned to blackish red i.e. pakvajambuphala varna. Bhasma was $75 \%$ rekhapurna. It was $60 \%$ varitara. On the trituration material was rough in nature.

$17^{\text {th }}$ Puta: On trituration in kharal bhasma was blackish red in colour. Bhasma was $85 \%$ rekhapurnna. $70 \%$ bhasma was found positive in varitara test.

$18^{\text {th }}$ Puta: Pellets were now soft and easily breakable by hand. Colour of bhasma was 
blackish red i.e. pakvajambuphala varna. Bhasma was $95 \%$ rekhapurna. $75 \%$ bhasma was found positive in varitara test.

BATCH "C": Batch "C" was prepared at the same method and same temperature which was adapted for batch A. Detail of findings and observations are given below.

\section{Batch "C"-Kanta lauha (Magnetite iron} ore)

\section{Samanya Sodhana by tila taila}

Method-Same as batch A

Observation -Same as Batch B

\section{Samanya Sodhana by Takra}

Method-Same as Batch A

Observations: First time Kanta lauha took 15 minute to obtain red hot state. The duration was lowered at later stages. When red hot Kanta lauha was quenched in takra, it was stared boiling. Colour of Kanta lauha was dark black. Colour of takra was also changed from white to blackish. Big particles of Kanta lauha was breaking into smaller size.

\section{Samanya Sodhana by Gomutra-}

Method-Same as Batch A

Observations: Iron took $15 \mathrm{~min}$. to get red hot state for first time then time duration was further lowered. After quenching peculiar smell was observed and Gomutra get started boiling. Colour of cow urine was changed from yellow to reddish black.Colour of Kanta lauha was also changed from black to reddish black. Kanta lauha was decreasing in size further.

\section{Samanya Sodhana by Kanji-}

Method - Same as Batch A

Observations: Kanta lauha took 10-12 min. to obtain red hot state. Further it was lowered. Kanji was started boiling after quenching the red hot Kanta lauha. Kanta lauha were converted to smaller pieces. Colour of Kanta lauha was black. Colour of Kanji was also changed from whitish to blackish.

Samanya Sodhana by Kullatha Kwath
Method- Same as Batch A

Observations: Kanta lauha took 10-12 min. to obtain red hot state. Further it was lowered. Kullatha kwatha was started boiling after quenching the Kanta lauha. Colour of kullatha kwatha was changed after quenching from red to blackish red. Particle of Kanta lauha become smaller.

B) Vishesha Sodhana of lauha

(b) Process of Vishesha sodhana

Ingredients- Kanta lauha (Magnetite iron ore) - 480 gm. Triphala kwatha - QS.

Method- Same as Batch A

Table No. 3. Showing observations before and after Visesha sodhana of Kanta lauha (Magnetite iron ore).

\begin{tabular}{|c|c|c|}
\hline Kanta Lauha & $\begin{array}{c}\text { Before } \\
\text { Vishesha } \\
\text { Sodhana }\end{array}$ & $\begin{array}{c}\text { After } \\
\text { Vishesha } \\
\text { Sodhana }\end{array}$ \\
\hline Colour & $\begin{array}{c}\text { Brownish } \\
\text { black }\end{array}$ & Dark black \\
\hline Consistency & brittle & More brittle \\
\hline Appearance & $\begin{array}{c}\text { Small } \\
\text { peaces }\end{array}$ & $\begin{array}{c}\text { More small } \\
\text { peaces }\end{array}$ \\
\hline Weight & $480 \mathrm{gm}$ & $510 \mathrm{gm}$ \\
\hline
\end{tabular}

Reason of wt. gain-Because adding of contents of Triphala kwatha. Out of this $20 \mathrm{gm}$ was taken as sample for analysis.

(II) Marana of Kanta lauha: Same as Batch A

\section{(I) Bhanupaka-}

Equipments required- iron tray, spatula'

Ingredients- Kanta Lauha churna- 490 gm. Triphala kwatha- QS.

Method: Same as Batch A

Method of Bhanupaka: Same as Batch A

Observations: It was taking 2-3 days for completely drying for one avartana. First time quantity of triphala kwatha was 300 $\mathrm{ml}$ to be used and further it was increased. Colour of Kanta lauha churna was dark black. Big particles of Kanta lauha churna 
were converted into smaller particles. Brittleness of Kanta lauha was increased.

Reason of wt. gain-Because addition of some solid contents of triphala kwatha with the Kanta lauha.

\section{(II) Sthalipaka}

Equipments required- Heating device, iron container, spatula etc.

Ingredients- Lauha churna- 1225 gm. Triphala kwatha- QS.

Method of sthalipaka: Same as previous batch

Observation: Same as previous batch

(II) Putpaka

Equipments required: Earthen pot, Electric muffle furnace, Mechanized kharala etc.

Ingredients: Lauha churna- 1735 gm. Triphala Kwath- QS.

Method Same as Batch A

$\mathbf{1}^{\text {st }}$ puta: It was taking 8 hour to get converted in pest like structure to made pellets. Due to coarse powder of materials, it was very difficult to made pellets. Temperature was set at $600^{\circ} \mathrm{C}$ and frequency at 30 . It was attain in 1 hour and 10 min. After puta colour of pellets was black. Surface of pellets was rough and cracked. After puta whole material was remain half of the original volumes, because of triphala contents which were added during bhanupaka and sthalipaka, burnt during putapaka. After triturating again powder was converted into black colour.

$2^{\text {nd }}$ puta: Material was triturated Approx. 6 hour. Some particles of Kanta lauha was remain as such which are not converted into powder form. Surface of pellets were rough. After puta colour of pellets was bluish black. But surface of some pellets was brown in colour. Pellets were soft and easily breakable by hand. After trituration it was again black in colour.

$3^{\text {rd }}$ puta: Same as batch B $4^{\text {th }}$ puta: Pellets were soft in consistency and easily breakable by hand. Colour of pellets was reddish brown but inside it was black. After trituration bhasma was brown in colour.

$5^{\text {th }}$ puta: Pellets were soft in consistency and easily breakable. Colour of pellets was reddish brown. Surface of pellets was rough. $20 \%$ bhasma was rekhapurna.

Reason of loss: Because burning of triphala contents. Out of this $20 \mathrm{gm}$ was taken as sample for analysis.

$6^{\text {th }}$ puta: Same as previous puta.

$7^{\text {th }}$ puta: Colour of pellets was light red. Consistency of pellets was soft. Surface of pellets was rough.

$8^{\text {th }}$ Puta: Pellets were soft they were getting broken by mild pressure of finger. Colour of pellets was same as previous.

$9{ }^{\text {th }}$ Puta: Pellets which were kept over the periphery remains blackish, but inner pellets were reddish brown in colour. Bhasma was $40 \%$ rekhapurna

10 ${ }^{\text {th }}$ Puta: Pellets were little hard then previous. Colour of pellets was turned to reddish black. Surface of pellets was smooth. $45 \%$ bhasma was rekhapurna.

$1^{\text {th }}$ Puta: Same as previous.

12 $^{\text {th }}$ Puta: Pellets were soft on breaking by hand. 50\% Bhasma was Rekhapurna. Material was rough during triturating in khalva.

$13^{\text {th }}$ Puta: Same as previous.

$14^{\text {th }}$ Puta: Same as previous.

15 $^{\text {th }}$ Puta: Pellets were little hard. Colour of pellets was slightly blackish red. Bhasma was became $60 \%$ rekhapurna. $50 \%$ bhasma was found positive in varitara test.

16 $^{\text {th }}$ Puta: Colour of bhasma was turned to blackish red i.e. pakvajambuphala varna. Bhasma was $80 \%$ rekhapurna. It was $65 \%$ varitara. On the trituration material was rough in nature. Weight of material after Bhavana- 425 gm. Weight of material after puta-420 gm. 
$17^{\text {th }}$ Puta: Pellets were soft in consistency then Teekshna lauha. On trituration in kharal bhasma was blackish red in colour. Bhasma was $85 \%$ found in rekhapurnna test. $70 \%$ bhasma was found positive in varitara test.

$18^{\text {th }}$ Puta: Pellets were now soft and easily breakable by hand. Colour of bhasma was blackish red i.e. pakvajambuphala varna. Bhasma was $95 \%$ rekhapurna. $75 \%$ bhasma was found positive in varitara test.

\section{Discussion:}

Conversion of metals and minerals into acceptable form i.e. bhasma is a unique technology of Ayurveda. This pharmaceutical study was done on the basis of Resendra Sara Samgraha to find out the best method for the preparation of lauha bhasma, as well as find out the best lauha bhasma. in this study it was found that kanta lauha is best for bhasma and next is teekshna lauha. Kanta lauha bhasma was well prepared in less putas then teekshna lauha.

\section{Conclusion:}

1. Certain technical procedures like Sodhana, Marana (Incineration process) etc. will play a greater role in converting the material into acceptable form.

2. . Here in present work a step is made to find out the best quality of lauha bhasma by preparing various samples of lauha bhasma. Two samples of Kanta lauha are used for preparation of lauha bhasma and one sample of Teekshna lauha is used for the preparation of lauha bhasma
3. Kanta lauha Bhasma was prepared in 18 putas and this Kanta lauha Bhasma was meeting all the best qualities of lauha Bhasma, where as Teekshna lauha Bhasma was prepared in 20 putas.

4. As per the description of Ayurveda, Kanta lauha (Magnetite iron ore) is considered as best raw material for lauha bhasma preparation. After this next best raw material for lauha bhasma preparation is Teekshna lauha (iron turnings).

\section{References:}

1. Shastri Ambika Datta, Sushruta Samhita, Chowkhamba Sanskrit Sansthan, 1987, Varanasi.

2. AFI- II, Volume- I, First Edition, Dept. of AYUSH, New Delhi.

3. Bhatt Sri Gopala Krishna, Resendra Sara Samgraha 1/297, Edited by Vaidya Satyarth Prakash, $1^{\text {st }}$ Edition, Krishnadas Academy Publishers, 1992, Varanasi.

4. Bhatt Sri Gopala Krishna, Resendra Sara Samgraha 1/302, Edited by Vaidya Satyarth Prakash, $1^{\text {st }}$ Edition, Krishnadas Academy Publishers, 1992, Varanasi.

5. Bhatt Sri Gopala Krishna, Resendra Sara Samgraha 1/305-06, Edited by Vaidya Satyarth Prakash, $1^{\text {st }}$ Edition, Krishnadas Academy Publishers, 1992, Varanasi.

6. Bhatt Sri Gopala Krishna, Resendra Sara Samgraha 1/316-18, Edited by Vaidya Satyarth Prakash, $1^{\text {st }}$ Edition, Krishnadas Academy Publishers, 1992, Varanasi. 
Table No. 4. Showing Weight of material, before and after puta.

\begin{tabular}{|c|c|c|c|c|c|c|c|}
\hline \multirow[t]{2}{*}{ S.No. } & \multirow{2}{*}{$\begin{array}{l}\text { No. } \\
\text { of } \\
\text { Puta } \\
\end{array}$} & \multicolumn{2}{|c|}{ Weight of Batch A } & \multicolumn{2}{|c|}{ Weight of Batch B } & \multicolumn{2}{|c|}{ Weight of Batch C } \\
\hline & & $\begin{array}{l}\text { Before } \\
\text { puta }\end{array}$ & $\begin{array}{l}\text { After } \\
\text { puta }\end{array}$ & $\begin{array}{l}\text { Before } \\
\text { puta }\end{array}$ & $\begin{array}{l}\text { After } \\
\text { puta }\end{array}$ & $\begin{array}{l}\text { Before } \\
\text { puta }\end{array}$ & $\begin{array}{l}\text { After } \\
\text { puta }\end{array}$ \\
\hline 1. & 1. & $2280 \mathrm{gm}$. & $1500 \mathrm{gm}$. & 1960 gm. & $1200 \mathrm{gm}$ & $1735 \mathrm{gm}$. & $980 \mathrm{gm}$. \\
\hline 2. & 2. & $1480 \mathrm{gm}$. & $1000 \mathrm{gm}$ & 1180 gm. & $900 \mathrm{gm}$. & 960 gm. & $850 \mathrm{gm}$. \\
\hline 3. & 3. & $1000 \mathrm{gm}$. & $650 \mathrm{gm}$. & $900 \mathrm{gm}$. & $600 \mathrm{gm}$. & $850 \mathrm{gm}$. & $610 \mathrm{gm}$. \\
\hline 4. & 4. & $650 \mathrm{gm}$. & $600 \mathrm{gm}$. & $600 \mathrm{gm}$. & $550 \mathrm{gm}$. & $610 \mathrm{gm}$. & $550 \mathrm{gm}$. \\
\hline 5. & 5. & $600 \mathrm{gm}$. & $590 \mathrm{gm}$. & $550 \mathrm{gm}$. & $530 \mathrm{gm}$. & $550 \mathrm{gm}$. & $535 \mathrm{gm}$. \\
\hline 6. & 6. & $570 \mathrm{gm}$. & $550 \mathrm{gm}$. & $510 \mathrm{gm}$. & $490 \mathrm{gm}$. & $515 \mathrm{gm}$. & $500 \mathrm{gm}$. \\
\hline 7. & 7. & $550 \mathrm{gm}$. & $530 \mathrm{gm}$. & $490 \mathrm{gm}$. & $485 \mathrm{gm}$. & $500 \mathrm{gm}$. & $485 \mathrm{gm}$. \\
\hline 8. & 8. & $530 \mathrm{gm}$. & $510 \mathrm{gm}$. & $485 \mathrm{gm}$. & $480 \mathrm{gm}$. & $485 \mathrm{gm}$. & $480 \mathrm{gm}$. \\
\hline 9. & 9. & $510 \mathrm{gm}$ & $500 \mathrm{gm}$. & $480 \mathrm{gm}$. & $480 \mathrm{gm}$. & $480 \mathrm{gm}$. & $480 \mathrm{gm}$. \\
\hline 10. & 10. & $500 \mathrm{gm}$. & $495 \mathrm{gm}$. & $480 \mathrm{gm}$. & $480 \mathrm{gm}$. & $480 \mathrm{gm}$. & $480 \mathrm{gm}$. \\
\hline 11. & 11. & $475 \mathrm{gm}$ & $470 \mathrm{gm}$ & $460 \mathrm{gm}$. & $450 \mathrm{gm}$. & $460 \mathrm{gm}$. & $455 \mathrm{gm}$. \\
\hline 12. & 12. & $470 \mathrm{gm}$. & $470 \mathrm{gm}$. & $450 \mathrm{gm}$. & $450 \mathrm{gm}$. & $455 \mathrm{gm}$. & $450 \mathrm{gm}$. \\
\hline 13. & 13. & 470gm. & $460 \mathrm{gm}$. & $450 \mathrm{gm}$. & $450 \mathrm{gm}$. & $450 \mathrm{gm}$. & $450 \mathrm{gm}$. \\
\hline 14. & 14. & $460 \mathrm{gm}$. & $460 \mathrm{gm}$. & $450 \mathrm{gm}$. & $440 \mathrm{gm}$. & $450 \mathrm{gm}$. & $440 \mathrm{gm}$. \\
\hline 15. & 15. & $460 \mathrm{gm}$. & $455 \mathrm{gm}$. & $440 \mathrm{gm}$. & $440 \mathrm{gm}$. & $440 \mathrm{gm}$. & $440 \mathrm{gm}$. \\
\hline 16. & 16. & $435 \mathrm{gm}$. & $435 \mathrm{gm}$. & $420 \mathrm{gm}$. & $420 \mathrm{gm}$. & $420 \mathrm{gm}$. & $420 \mathrm{gm}$. \\
\hline 17. & 17. & $435 \mathrm{gm}$. & $435 \mathrm{gm}$. & $420 \mathrm{gm}$. & $410 \mathrm{gm}$. & $420 \mathrm{gm}$. & $410 \mathrm{gm}$. \\
\hline 18. & 18. & $435 \mathrm{gm}$. & $430 \mathrm{gm}$. & $410 \mathrm{gm}$. & $400 \mathrm{gm}$. & $410 \mathrm{gm}$. & $400 \mathrm{gm}$. \\
\hline 19. & 19. & $430 \mathrm{gm}$. & $430 \mathrm{gm}$. & & & & \\
\hline 20. & 20. & $430 \mathrm{gm}$. & $430 \mathrm{gm}$. & & & & \\
\hline
\end{tabular}

Table No. 5. Showing the quantity of ingredients taken in each Puta of different batches

\begin{tabular}{|l|l|l|l|l|}
\hline $\begin{array}{l}\text { S. } \\
\text { No. }\end{array}$ & $\begin{array}{l}\text { No. } \\
\text { of } \\
\text { Puta }\end{array}$ & Batch A & Batch B & Batch C \\
\hline & & Ingredients in gm. & Ingredients in gm. & Ingredients in gm. \\
\hline 1. & $\mathbf{1 .}$ & $\begin{array}{l}\text { Lauha churna-2280 } \\
\text { Triphala kwatha-QS }\end{array}$ & $\begin{array}{l}\text { Lauha churna-1960 } \\
\text { Triphala kwatha-QS }\end{array}$ & $\begin{array}{l}\text { Lauha churna-1735 } \\
\text { Triphala kwatha-QS }\end{array}$ \\
\hline 2. & $\mathbf{2 .}$ & $\begin{array}{l}\text { Lauha churna-1480 } \\
\text { Triphala kwatha -QS }\end{array}$ & $\begin{array}{l}\text { Lauha churna-1180 } \\
\text { Triphala kwatha-QS }\end{array}$ & $\begin{array}{l}\text { Lauha churna- 960 } \\
\text { Triphala kwatha-QS }\end{array}$ \\
\hline 3. & 3. & $\begin{array}{l}\text { Lauha churna-1000 } \\
\text { Triphala kwatha -QS. }\end{array}$ & $\begin{array}{l}\text { Lauha churna-900 } \\
\text { Triphala kwatha-QS. }\end{array}$ & $\begin{array}{l}\text { Lauha churna- } 850 \\
\text { Triphala kwatha-QS }\end{array}$ \\
\hline 4. & 4. & $\begin{array}{l}\text { Lauha churna-650 } \\
\text { Triphala kwatha -QS. }\end{array}$ & $\begin{array}{l}\text { Lauha churna-600 } \\
\text { Triphala kwatha-QS. }\end{array}$ & $\begin{array}{l}\text { Lauha churna-610 } \\
\text { Triphala kwatha -QS }\end{array}$ \\
\hline 5. & $\mathbf{5 .}$ & $\begin{array}{l}\text { Lauha churna-600 } \\
\text { Triphala kwatha -QS. }\end{array}$ & $\begin{array}{l}\text { Lauha churna-550 } \\
\text { Triphala kwatha-QS. }\end{array}$ & $\begin{array}{l}\text { Lauha churna-550 } \\
\text { Triphala kwatha -QS }\end{array}$ \\
\hline
\end{tabular}




\begin{tabular}{|c|c|c|c|c|}
\hline 6. & 6. & $\begin{array}{l}\text { Lauha churna-570 } \\
\text { Triphala kwatha-QS. }\end{array}$ & $\begin{array}{l}\text { Lauha churna-510 } \\
\text { Triphala kwatha-QS. }\end{array}$ & $\begin{array}{l}\text { Lauha churna-515 } \\
\text { Triphala kwatha -QS }\end{array}$ \\
\hline 7. & 7. & $\begin{array}{l}\text { Lauha churna-550 } \\
\text { Triphala kwatha-QS. }\end{array}$ & $\begin{array}{l}\text { Lauha churna-490 } \\
\text { Triphala kwatha-QS. }\end{array}$ & $\begin{array}{l}\text { Lauha churna-490 } \\
\text { Triphala kwatha-QS }\end{array}$ \\
\hline 8. & 8. & $\begin{array}{l}\text { Lauha churna-530 } \\
\text { Triphala kwatha-QS. }\end{array}$ & $\begin{array}{l}\text { Lauha churna-485 } \\
\text { Triphala kwatha-QS. }\end{array}$ & $\begin{array}{l}\text { Lauha churna-485 } \\
\text { Triphala kwatha-QS }\end{array}$ \\
\hline 9. & 9. & $\begin{array}{l}\text { Lauha churna-510 } \\
\text { Triphala kwatha-QS. }\end{array}$ & $\begin{array}{l}\text { Lauha churna- } 480 \\
\text { Triphala kwatha-QS. }\end{array}$ & $\begin{array}{l}\text { Lauha churna- } 480 \\
\text { Triphala kwatha-QS }\end{array}$ \\
\hline 10. & 10. & $\begin{array}{l}\text { Lauha churna-500 } \\
\text { Triphala kwatha-QS. }\end{array}$ & $\begin{array}{l}\text { Lauha churna- } 480 \\
\text { Triphala kwatha-QS. }\end{array}$ & $\begin{array}{l}\text { Lauha churna- } 480 \\
\text { Triphala kwatha -QS }\end{array}$ \\
\hline 11. & 11. & $\begin{array}{l}\text { Lauha churna-475 } \\
\text { Triphala kwatha-QS. }\end{array}$ & $\begin{array}{l}\text { Lauha churna-460 } \\
\text { Triphala kwatha-QS. }\end{array}$ & $\begin{array}{l}\text { Lauha churna-460 } \\
\text { Triphala kwatha }-Q S\end{array}$ \\
\hline 12. & 12. & $\begin{array}{l}\text { Lauha churna-470 } \\
\text { Triphala kwatha -QS. }\end{array}$ & $\begin{array}{l}\text { Lauha churna-450 } \\
\text { Triphala kwatha-QS }\end{array}$ & $\begin{array}{l}\text { Lauha churna-455 } \\
\text { Triphala kwatha-QS }\end{array}$ \\
\hline 13. & 13. & $\begin{array}{l}\text { Lauha churna-470 } \\
\text { Triphala kwatha -QS. }\end{array}$ & $\begin{array}{l}\text { Lauha churna-450 } \\
\text { Triphala kwatha-QS }\end{array}$ & $\begin{array}{l}\text { Lauha churna-450 } \\
\text { Triphala kwatha-QS }\end{array}$ \\
\hline 14. & 14. & $\begin{array}{l}\text { Lauha churna-460 } \\
\text { Triphala kwatha-QS. }\end{array}$ & $\begin{array}{l}\text { Lauha churna-450 } \\
\text { Triphala kwatha-QS }\end{array}$ & $\begin{array}{l}\text { Lauha churna-450 } \\
\text { Triphala kwatha-QS }\end{array}$ \\
\hline 15. & 15. & $\begin{array}{l}\text { Lauha churna- } 460 \\
\text { Triphala kwatha-QS. }\end{array}$ & $\begin{array}{l}\text { Lauha churna-440 } \\
\text { Triphala kwatha-QS }\end{array}$ & $\begin{array}{l}\text { Lauha churna-440 } \\
\text { Triphala kwatha-QS }\end{array}$ \\
\hline 16. & 16. & $\begin{array}{l}\text { Lauha churna-435 } \\
\text { Triphala kwatha-QS. }\end{array}$ & $\begin{array}{l}\text { Lauha churna-420 } \\
\text { Triphala kwatha-QS }\end{array}$ & $\begin{array}{l}\text { Lauha churna-420 } \\
\text { Triphala kwatha-QS }\end{array}$ \\
\hline 17. & 17. & $\begin{array}{l}\text { Lauha churna-435 } \\
\text { Triphala kwatha-QS. }\end{array}$ & $\begin{array}{l}\text { Lauha churna-420 } \\
\text { Triphala kwatha-QS }\end{array}$ & $\begin{array}{l}\text { Lauha churna-420 } \\
\text { Triphala kwatha-QS. }\end{array}$ \\
\hline 18. & 18. & $\begin{array}{l}\text { Lauha churna-435 } \\
\text { Triphala kwatha-QS. }\end{array}$ & $\begin{array}{l}\text { Lauha churna-410 } \\
\text { Triphala kwatha-QS }\end{array}$ & $\begin{array}{l}\text { Lauha churna-410 } \\
\text { Triphala kwatha-QS. }\end{array}$ \\
\hline 19. & 19. & $\begin{array}{l}\text { Lauha churna-430 } \\
\text { Triphala kwatha-QS. }\end{array}$ & - & - \\
\hline 20. & 20. & $\begin{array}{l}\text { Lauha churna-430 } \\
\text { Triphala kwatha-QS. }\end{array}$ & - & - \\
\hline
\end{tabular}




\section{Photo 1: Processing of Puta in Electric Muffle Furnace}

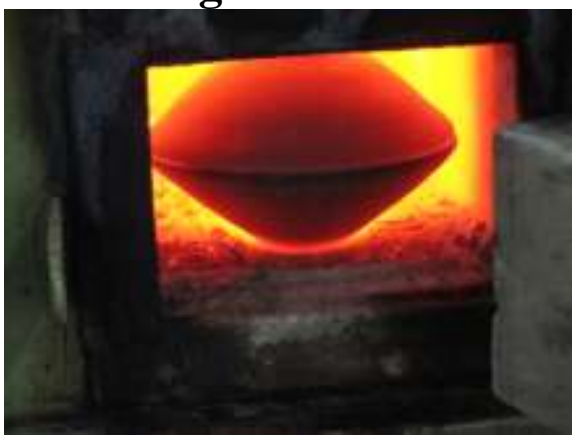

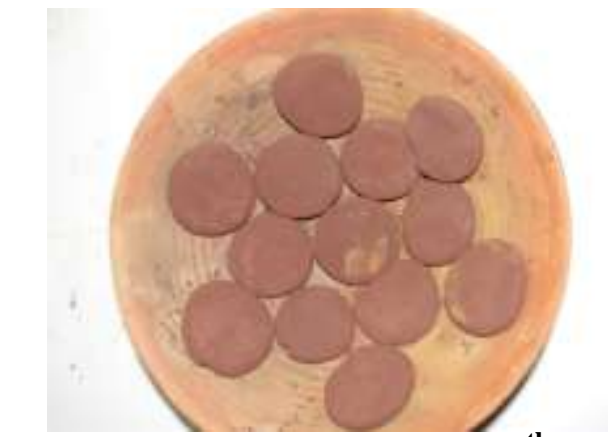

Pellets of Kanta lauha after $5^{\text {th }}$ Puta

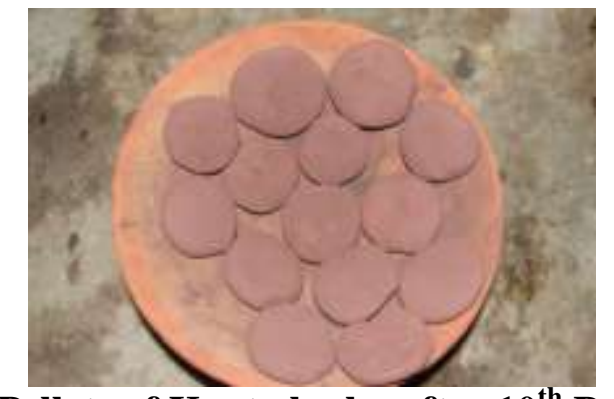

Pellets of Kanta lauha after $10^{\text {th }}$ Puta

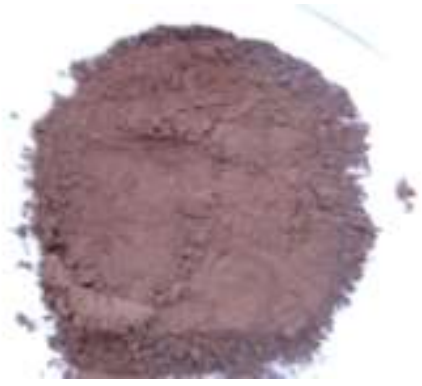

Kanta Lauha Bhasma after $18^{\text {th }}$ Puta

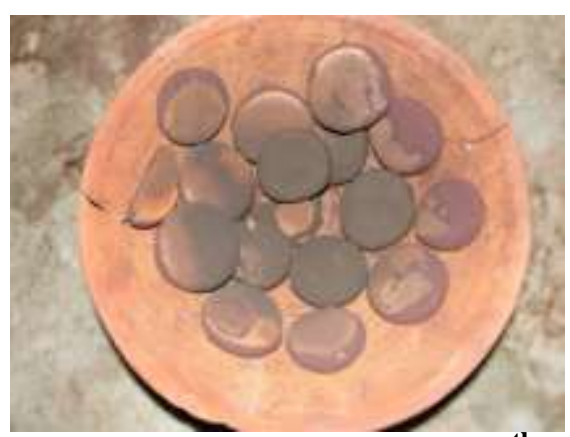

Pellets of Teekshna lauha after $5^{\text {th }}$ Puta
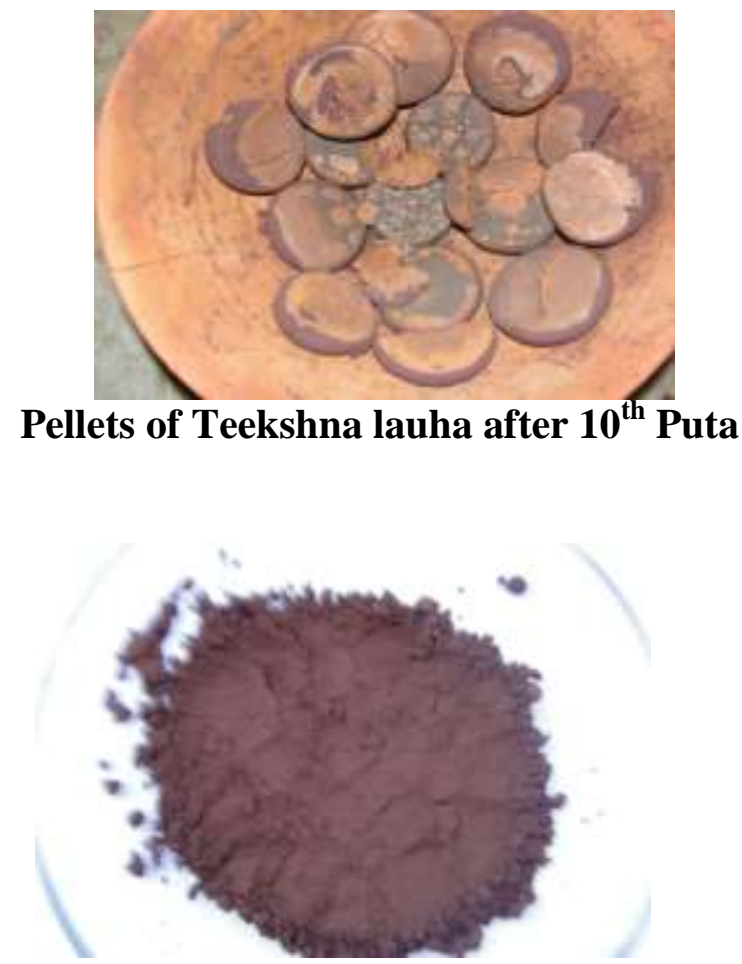

Teekshna Lauha Bhasma after $20^{\text {th }}$ Puta 


\section{Photo 2: Lauha Sodhana}

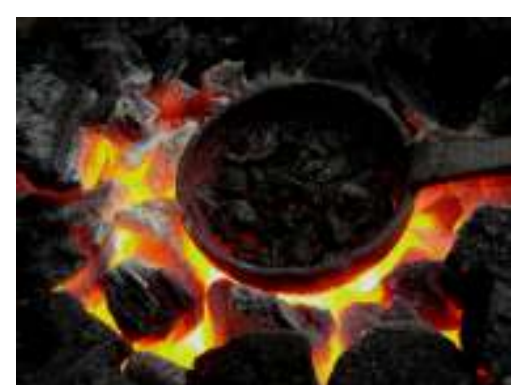

Magnetite iron ore in Red hot state

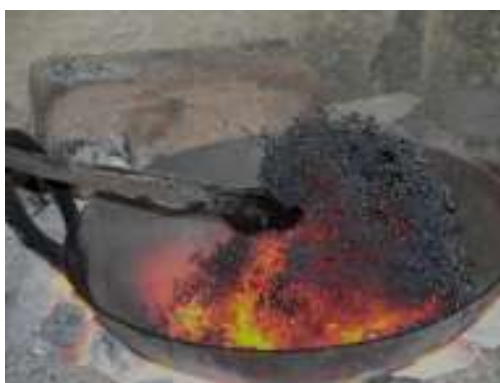

Iron turnings in Red hot state

\section{Photo 3: Sodhana Media}

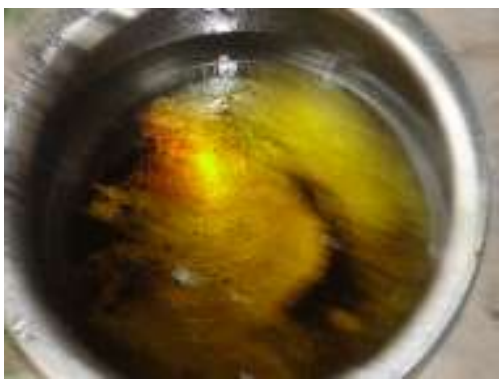

Tila taila (Sesamum oil)

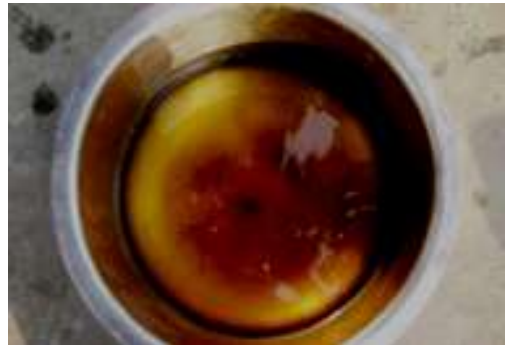

Gomutra (Cow Urine)

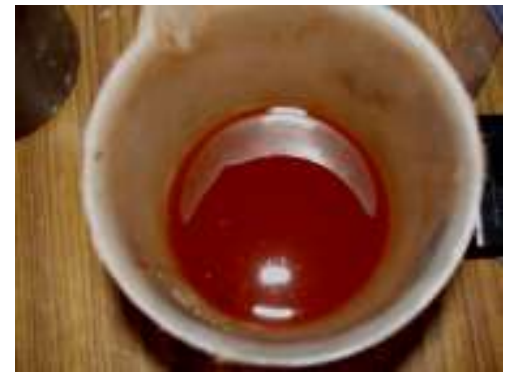

Kullatha Kwatha

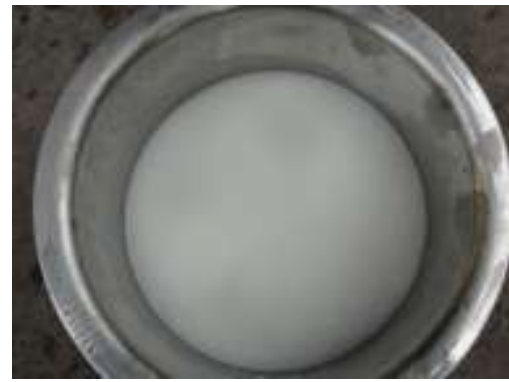

Takra (Butter Milk)

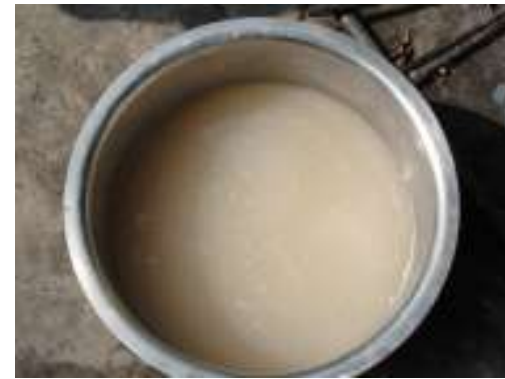

Kanji (Sour gruel)

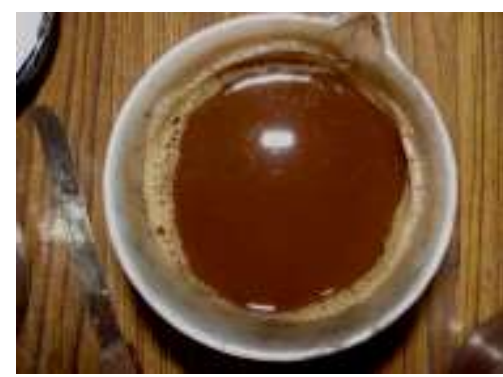

Triphala Kwatha 